\title{
Xylanase Pretreatment of Mechanically Destructured Chips of Eucalyptus tereticornis and its Effect on Kraft Pulping
}

\author{
Laxman Kumar Pandey, ${ }^{\mathrm{a}}$ Amit Kumar, ${ }^{\mathrm{b}, *}$ Surendra Pal Singh, ${ }^{\mathrm{a}}$ and Dharm Dutt, ${ }^{\mathrm{a}, *}$ \\ Mechanical pulping of raw wood material is a highly energy intensive and \\ pollution generating step in the papermaking process. This study focused \\ on combined mechanical and xylanase treatment prior to the kraft pulping \\ of E. tereticornis. A screened pulp yield of $49.1 \%$ (on oven-dry wood basis) \\ with a Kappa number of 24.9 was obtained at the optimum cooking \\ temperature of $160{ }^{\circ} \mathrm{C}$ without any pretreatment of the wood chips. After \\ mechanical treatment (destructuring), a slightly higher screened pulp yield \\ $(49.4 \%)$ was obtained with a Kappa number of 24.2 at the cooking \\ temperature of $145{ }^{\circ} \mathrm{C}$ with the same active alkali charge (15\%). The \\ optimum cooking temperature was further reduced to $140{ }^{\circ} \mathrm{C}$ for the \\ destructured xylanase-treated wood chips. The xylanase treatment \\ resulted in a $2 \%$ reduction in screened pulp yield due to hydrolysis of xylan. \\ However, the Kappa number was reduced to 18.2 after xylanase \\ pretreatment of the mechanically destructured wood chips. The combined \\ pretreatment (destructured and xylanase treatment) of wood chips \\ resulted in a reduction in cooking temperature by $20^{\circ} \mathrm{C}$ compared to \\ untreated wood chips. Such a reduction in cooking temperature can \\ effectively reduce steam consumption. The combined pretreatment \\ improved the pulp brightness by 2.0 (ISO points) and physical strength \\ properties, which included the tensile index, tear index, and burst index by \\ $11.06 \%, 21.72 \%$, and $21.79 \%$, respectively, compared to the control.
}

Keywords: Eucalyptus tereticornis; Xylanase pretreatment; Chemical pulping; Biopulping; Impressafiner; Kraft pulping

Contact information: a: Department of Paper Technology, Indian Institute of Technology Roorkee, India; b: Department of Biotechnology, College of Natural and Computational Sciences, Debre Markos University, Debre Markos, Ethiopia;

*Corresponding authors: dharm.dutt@pt.iitr.ac.in; baliyaniitr@gmail.com

\section{INTRODUCTION}

The pulp and paper industry is the $6^{\text {th }}$ largest pollution-generating industry, and it produces solid, liquid, and gaseous wastes (Söderholm et al. 2019). In addition, it is the $4^{\text {th }}$ most energy-intensive manufacturing industry. Pulping, bleaching, and papermaking are the three basic steps in the paper manufacturing process (Ezeudu et al. 2019; Sharma et al. 2020; Gautam et al. 2021). The pulping process involves the cleavage of lignocellulosic linkages in the woody structure to separate cellulosic fibers by dissolving (chemical pulping) or breaking (mechanical pulping) the middle lamella so that the individual fibers can be utilized for papermaking. During chemical pulping, raw materials are cooked with the appropriate chemicals in aqueous solution at high temperature and pressure. Chemical pulping consumes high amounts of energy and chemicals, and it is considered one of the main sources of pollution in the pulp and paper industry (Kumar et al. 2020). 
Environmental regulations have pushed the industry to develop green alternatives for pulp and paper processing. The fungal pre-treatment of wood chips prior to mechanical or chemical pulping is known as biopulping. White-rot fungus has been shown to degrade the lignin selectively in wood after colonization, thereby leaving cellulose relatively intact. Biopulping is an energy-efficient and environmentally-friendly approach to minimize pollution generation and energy consumption during pulping. The biopulping process reduces chemical consumption, pulping time, lignin content, and Kappa numbers. Biological pretreatment decreases the energy requirement of pulping and improves the physical strength properties of paper (Bari et al. 2021). Fungal treatment also has several limitations. Fungal treatment can decrease the brightness of pulp after a long treatment time. Longer incubation times, which typically range from 2 weeks to 8 weeks, were effective in terms of chemical consumption, pulping time, and lignin content reduction, since it is understood that lignin content tends to be detrimental to industrial application of the fibers. Moreover, effective colonization by white-rot fungi requires the raw materials to be in a state of asepsis (Bajpai 2018; Kumar et al. 2020). If enzyme is used as a pretreatment agent, such limitations of biopulping can be avoided. Recently, several studies have reported the effect of xylanase pretreatment on chemical pulping (Varghese et al. 2020a,2020b; Akgül et al. 2021). Xylanase pretreatment facilitates the separation of fibrils in the initial stage of fibrillation via the removal of easily accessible xylan, which is mainly located among micrometer-sized cellulose fibrils (Zhou et al. 2019; Akgül et al. 2021; Kumar 2021). The pretreatment of sugarcane bagasse and wheat straw with xylanopectinolytic enzyme reduced pulping chemical consumption by 12 to $15 \%$ during kraft pulping. In addition, the superior physical strength properties were observed due to enzymatic treatment of the substrate (Varghese et al. 2020a,b). Akgül et al. (2021) evaluated the effect of xylanase pretreatment on the kraft pulping of poplar and reported improved yield and pulp viscosity after xylanase pretreatment. Further, the xylanase pretreatment resulted in remarkable improvement in the tensile index, breaking length, and burst index. The mechanical pre-treatment with Impressafiner resulted in partial disintegration of chips into fragmented chips with cracks and reduced the electrical energy consumption of pre-treated Norway spruce chips to achieve a tensile index of $47 \mathrm{Nm} / \mathrm{g}$ by $120 \mathrm{kWh} / \mathrm{bdt}$, i.e. $6 \%$ (Nelsson et al. 2018).

This study evaluated the effect of combined mechanical and xylanase treatment on the kraft pulping of E. tereticornis chips. Eucalyptus is an important type of hardwood that is grown in 18 million ha in 90 countries under temperate, tropical, and subtropical climates for industrial and commercial purposes, such as timber and papermaking. Different species of the genus Eucalyptus exhibit rapid growth and are cultivated in many countries. $E$. tereticornis is mainly grown in India and was selected for this study (Rockwood et al. 2008; Knapic et al. 2014; Neiva et al. 2015).

\section{EXPERIMENTAL}

\section{Collection of Raw Material and Chemical Composition}

Eucalyptus tereticornis chips of thickness 4 to $6 \mathrm{~mm}$ were collected from ITC Bhadrachalam (Telangana, India). The chips were washed with water and manually chopped into small pieces of approximately 3.0 to $5.0 \mathrm{~cm}$. The chopped chips were dried in sunlight until reaching the desired moisture content and stored in polythene bags for further use. Raw material was milled and the portion passed through -40 size mesh and 
retained on +80 was used for chemical composition analysis. Extractives were removed using Soxhlet apparatus and mixture of ethanol-benzene $(1: 2 \mathrm{v} / \mathrm{v})$ before compositional analysis as per TAPPI test method TAPPI T264 cm-97(1997). Extractive free samples were subjected to $\alpha$-cellulose (TAPPI T203 cm-99 (1999)), holocellulose (TAPPI T249 cm85(2009)), and lignin (TAPPI T222 om-02(2006)) determination.

\section{Mechanical Treatment by Impressafiner}

The wood chips were destructured by passing them through a wood destructuring machine (Impressafiner, Universal Engineering Corporation, Saharanpur, India) (Fig. 1) to reach the size of the spongy structure of about $25 \times 25 \times 4 \mathrm{~mm}$. The wood chips were soaked in tap water overnight. After draining the water, the soaked chips were dewatered in a compression-cum dewatering unit (Universal Engineering Corporation, Saharanpur, India) at 10 RPM and 5800 psi. The unit completely compressed the chips and squeezed out soluble materials and water. The feeding capacity of the machine was 1 to $2 \mathrm{~kg}$. The destructuring of $1 \mathrm{~kg}$ of wood chips took $5 \mathrm{~min}$ and resulted in a spongy material without damaging the fibers. The destructured material was homogenized in a single lot to avoid compositional differences among aliquots and stored for further use.

The Impressafiner compressed and delaminated the chips to open the wood structure before refining, minimize variation in moisture content, maximize the removal of extractives, reduce variation in bulk density, and reduce the energy consumption during subsequent refining. The Impressafiner is designed to compress the chips to a uniform size distribution as they proceeded to the discharge of the compression screw press. The structural changes in the wood chips accelerated and improved the uniformity of heating, thus allowing a reduction in time required to soften the wood. The high compression squeezed out extractives and dissolved organic substances. Special attention had to be given to the retention time and pressure. High pressure and long retention time typically resulted in an increase in pulp strength but a decrease in pulp brightness (undesirable darkening reactions) (Fig. 2) (Sabourin et al. 2002).

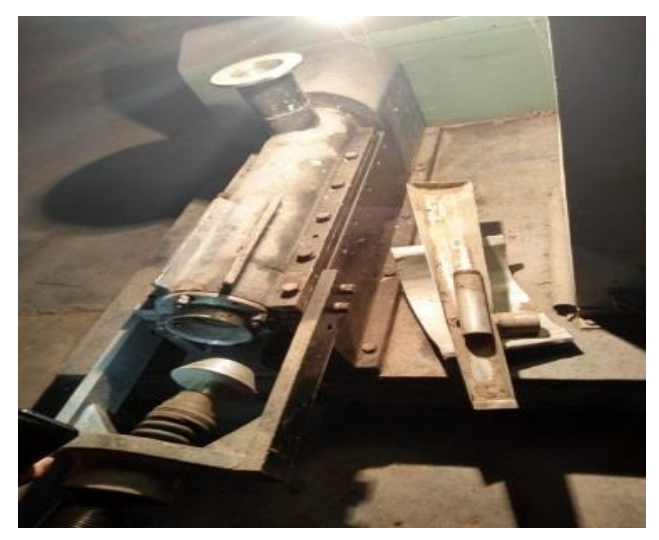

Fig. 1. Wood destructuring machine (Impressafiner)

\section{Xylanase Pretreatment}

The commercial xylanase preparation (Xylanase ex) was purchased from SRL Pvt. Ltd. (Taloja, India). The xylanase activity of the enzyme was determined according to Kumar et al. (2016a), using birchwood xylan (SRL Pvt. Ltd., Taloja, India) (Kumar et al. 2016a). Pretreatment of the destructured E. tereticornis wood samples was performed in 
separate conical flasks that contained $100 \mathrm{~g}$ (OD basis) of sample. Citrate buffer was added to the raw material (substrate) at a 3:1 ratio to maintain the $\mathrm{pH}$ at 5.0. The pretreatment of destructured wood chips was performed with an enzyme dose of $20 \mathrm{IU} / \mathrm{g}$ of OD samples and incubated at a temperature of $45^{\circ} \mathrm{C}$ for $12 \mathrm{~h}$ and as such the destructured wood was pretreated without deactivation of enzymes.

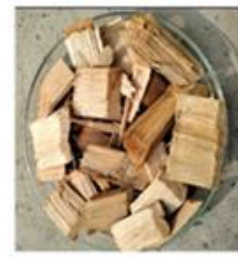

Wood chips

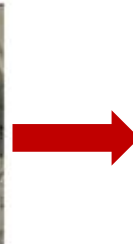

ROLL1 Compression of wood chips
(Karinkanta 2014)

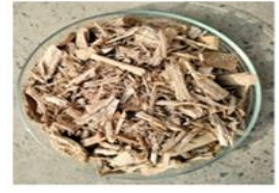

Destructured wood chips

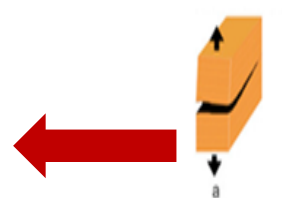

(a) Tensile stress leads to tensile failure (b0 In-plane or Forward stress failure and, (c) leading to out-of-plane or transverse failure (Karinkanta et al. 2018)

Fig. 2. Working principle of Impressafiner (Karinkanta 2014; Karinkanta et al. 2018)

\section{Pulping Studies}

Three different forms of E. tereticornis wood samples, which included nondestructured, destructured (mechanically treated), and destructured xylanase-treated (DXT) wood samples were cooked via the kraft pulping process. They were cooked at an alkali dose of $15 \% \mathrm{Na}_{2} \mathrm{O}$ in a WEVERK electrically heated rotary digester (Universal Engineering Corporation, Saharanpur, India) of $0.02 \mathrm{~m}^{3}$ capacity that had four bombs (metal container of 1-L capacity), each at a maximum temperature that ranged from 150 ${ }^{\circ} \mathrm{C}$ to $170{ }^{\circ} \mathrm{C}$. Cooking time ranged from 1.5 to $2 \mathrm{~h}$, and the liquor to raw material (OD basis) ratio was 3:1. Further, the pulps were washed on a laboratory flat stationary screen with a 300-mesh wire bottom to remove the black liquor. Then, the pulp was disintegrated and screened through a WEVERK vibratory flat screen (Universal Engineering Corporation, Saharanpur, India) with a $0.15-\mathrm{mm}$ slot size, and the screened pulp was washed with water, pressed, and crumbled. The pulp samples were analyzed for Kappa number as per TAPPI T236 om-99(1999), screened pulp yield, and screening rejects.

\section{Laboratory Handsheets Preparation and Analysis of Pulp and Paper Properties}

After pulping, the unbleached pulp samples were beaten in a PFI mill (Universal Engineering Corporation, Saharanpur, India) at a fixed beating level of $35^{\circ} \mathrm{SR}$. Laboratory handsheets of $60 \mathrm{~g} / \mathrm{m}^{2}$ were prepared using British sheet former (Universal Engineering Corporation, Saharanpur, India) as per TAPPI T205 sp-02(2002). Before determination of the physical strength properties, the handsheets were pre-conditioned at $23 \pm 2{ }^{\circ} \mathrm{C}$ and 
relative humidity of $50 \pm 2 \%$ as per TAPPI T402 sp-03, 2003). The physical strength properties, which included burst index (TAPPI T403 om-97, 1997), tear index (TAPPI T414 om-04, 2004), tensile index (TAPPI T494 om-01, 2001), and double fold numbers (TAPPI T423 cm-98, 1998)) were analyzed. Thick pads of $4 \pm 0.2 \mathrm{~g}$ were prepared as per TAPPI T218 sp-02, 2002 and brightness determination according to TAPPI T452 om-02, 2002.

\section{Field Emission-scanning Electron Microscopy (FE-SEM) and Fourier Transform Infrared Spectroscopy (FTIR) Analysis of Pulp Samples}

Morphological analyses of the pulp samples were performed by FE-SEM (TESCAN, MIRA 3 LMH, Libusina TR.21, Brno, Czech Republic). Pulp samples were dried before analysis and gold coated via a standard sputtering technique (Quorum, Leica EM ACE600, Libusina TR.21, Brno, Czech Republic) for 30 s. Samples were analyzed for morphological changes and images were captured at $15.0 \mathrm{kV}$ at desired magnifications. Fourier transform infrared spectroscopy is a method of calculating structural deviations in the samples due to the chemical treatments. Fourier transform infrared analysis of the nondestructured, destructured (mechanical treatment), and destructured-xylanse pretreated pulp samples was performed using a FTIR (Perkin-Elmer, Singapore Pvt. Ltd., L1600400 Spectrum TWO DTGS, Ayer Rajah, Singapore) spectrophotometer. The samples were oven dried at $105{ }^{\circ} \mathrm{C}$ for $4 \mathrm{~h}$ to $5 \mathrm{~h}$ and mixed with $\mathrm{KBr}$ to prepare the pellets. The sample spectra were recorded in transmittance mode at the wavenumber range 4000 to $500 \mathrm{~cm}^{-1}$.

\section{Statistical Analysis}

All experiments were carried out in triplicate, and the experimental results were analyzed by Origin Pro 8.5 (OriginLab Corporation, Northampton, MA, USA) software. All the results were recorded as the mean \pm standard deviation of values.

\section{RESULTS AND DISCUSSION}

\section{Pulping of Non-destructured Wood Chips of E. tereticornis}

The proximate analysis of E. tereticornis showed that it contained 43.2\%, 73.2\%, and $27.1 \%$ of $\alpha$-cellulose, holocellulose, and lignin content, respectively. According to the rating system designated by Nieschlag et al. (1960), cellulosic plants having more than $34 \% \alpha$-cellulose were characterized as promising for pulp and paper making for the chemical composition point of view because $\alpha$-cellulose had undegraded and high molecular weight cellulose contents in the pulp. On the other hand, $\beta$-cellulose was degraded cellulose and $\gamma$-cellulose consisted of low molecular weight hemicelluloses. Kraft pulping of non-destructed wood chips was performed at cooking temperatures that ranged from 150 to $170{ }^{\circ} \mathrm{C}$ using $15 \%$ active alkali $\left(\mathrm{Na}_{2} \mathrm{O}\right)$, and the other conditions, such as pulping time and bath ratio, remained constant (Table 1). When cooking temperature was increased from 150 to $160{ }^{\circ} \mathrm{C}$ and $\mathrm{H}$-factor 290-691, the pulp yield and Kappa number decreased. Beyond a cooking temperature of $160{ }^{\circ} \mathrm{C}$ and $\mathrm{H}$-factor 691, Kappa number was decreased slightly, and the screened pulp yield decreased sharply. In addition, the screened pulp yield decreased sharply, which may have been because of the degradation of cellulose due to the peeling reaction mechanism (Pandey et al. 2012). Higher temperature results in faster delignification and additional degradation (secondary peeling) of carbohydrates, which decreases the screened pulp yield (Lal et al. 2010). The optimum screened pulp yield 
of $49.1 \%$ with a Kappa number of 24.9 was obtained at a maximum temperature of $160{ }^{\circ} \mathrm{C}$, and other conditions were kept constant. Therefore, $160{ }^{\circ} \mathrm{C}$ was judged to be the optimum temperature for the pulping of the non-destructed wood chips of E. tereticornis.

Table 1. Pulping of the Non-destructured Wood Chips of E. tereticornis

\begin{tabular}{|c|c|c|c|c|c|c|}
\hline Parameter & $\begin{array}{c}\mathrm{H}- \\
\text { factor }\end{array}$ & $\begin{array}{c}\text { Pulp Yield } \\
(\%)\end{array}$ & $\begin{array}{c}\text { Screen } \\
\text { Rejects } \\
(\%)\end{array}$ & $\begin{array}{c}\text { Screened } \\
\text { Pulp Yield } \\
(\%)\end{array}$ & Kappa No. & Pulping Conditions \\
\hline \multicolumn{7}{|c|}{ Temperature $\left({ }^{\circ} \mathrm{C}\right)$ Variation } \\
\hline $150 \pm 2$ & 290 & $51.1 \pm 0.52$ & $2.70 \pm 0.11$ & 48.4 & $33.8 \pm 0.32$ & \multirow{5}{*}{$\begin{array}{l}\text { Time from ambient } \\
\text { temperature to } 105^{\circ} \mathrm{C}= \\
45 \text { min, time from } 105^{\circ} \mathrm{C} \\
\text { to maximum temperature } \\
=60 \text { min, time at } \\
\text { maximum temperature = } \\
90 \text { min, bath ratio }=1: 3 \text {, } \\
\text { active alkali } 15 \%\left(\mathrm{Na}_{2} \mathrm{O}\right) \text {, } \\
\text { sulphidity }=25 \%\end{array}$} \\
\hline $155 \pm 2$ & 450 & $50.5 \pm 0.31$ & $1.90 \pm 0.05$ & 48.6 & $26.3 \pm 0.41$ & \\
\hline $160 \pm 2$ & 691 & $49.8 \pm 0.48$ & $0.57 \pm 0.08$ & 49.1 & $24.9 \pm 0.27$ & \\
\hline $165 \pm 2$ & 1051 & $48.1 \pm 0.40$ & $0.35 \pm 0.04$ & 47.5 & $23.7 \pm 0.43$ & \\
\hline $170 \pm 2$ & 1585 & $47.3 \pm 0.24$ & $0.23 \pm 0.03$ & 47.3 & $21.6 \pm 0.21$ & \\
\hline \multicolumn{7}{|c|}{ Active Alkali (\%) Variation } \\
\hline 12 & & $50.9 \pm 0.32$ & $2.50 \pm 0.10$ & 47.8 & $30.4 \pm 0.32$ & \multirow{6}{*}{$\begin{array}{l}\text { Time from ambient } \\
\text { temperature to } 105^{\circ} \mathrm{C}= \\
45 \mathrm{~min} \text {, time from } 105^{\circ} \mathrm{C} \\
\text { to } 160^{\circ} \mathrm{C}=60 \mathrm{~min} \text {, time } \\
\text { at } 160^{\circ} \mathrm{C}=90 \mathrm{~min} \text {, bath } \\
\text { ratio }=1: 3, \\
\text { sulphidity }=25 \% \text {, active } \\
\text { alkali doses }=\text { varied from } \\
12 \% \text { to } 20 \%\left(\mathrm{Na}_{2} \mathrm{O}\right)\end{array}$} \\
\hline 14 & & $50.1 \pm 0.15$ & $1.70 \pm 0.12$ & 48.4 & $26.8 \pm 0.28$ & \\
\hline 15 & & $49.8 \pm 0.48$ & $0.57 \pm 0.08$ & 49.1 & $24.9 \pm 0.27$ & \\
\hline 16 & & $48.0 \pm 0.33$ & $0.25 \pm 0.11$ & 47.7 & $24.6 \pm 0.10$ & \\
\hline 18 & & $46.5 \pm 0.37$ & $0.15 \pm 0.13$ & 46.4 & $23.1 \pm 0.45$ & \\
\hline 20 & & $45.1 \pm 0.16$ & $0.10 \pm 0.10$ & 45.0 & $22.4 \pm 0.12$ & \\
\hline
\end{tabular}

Active alkali influences effective delignification during kraft pulping. In another set of experiments, the active alkali doses were varied from $12 \%$ to $20 \%\left(\mathrm{Na}_{2} \mathrm{O}\right)$, and the other conditions remained constant. Table 2 showed that the screened pulp yield of $E$. tereticornis wood chips improved as the active alkali increased to $15 \%\left(\mathrm{Na}_{2} \mathrm{O}\right)$, and beyond a $15 \%$ active alkali dose, the screened pulp yield started to decline. The pulp Kappa number decreased sharply up to a $15 \%$ alkali dose, and beyond $15 \%$ the decrease in Kappa number was insignificant. Therefore, an optimum active alkali of $15 \%$ gave a reasonable screened pulp yield with the minimum Kappa number and was selected as the optimum dose for the pulping of non-destructured wood chips of E. tereticornis. The screened pulp yield and Kappa number of the resultant pulp were controlled by the active alkali dose during kraft pulping (Gautam et al. 2016). The kraft pulping process is an alkaline process that utilizes $\mathrm{NaOH}$ and $\mathrm{Na}_{2} \mathrm{~S}$ as active chemicals in the white liquor for lignin degradation and the liberation of fibers. The hydroxide ion $(\mathrm{HO})$, hydrogen sulphide ions $\left(\mathrm{HS}^{-}\right)$, and carbanions were generated during kraft pulping, and they competed to react with lignin. The delignification rate is substantially higher in kraft pulping than in soda pulping because HS $^{-}$ion improves the rate of lignin degradation by specifically promoting the rate of cleavage of $\beta$-aryl-ether linkages in the phenolic units of lignin (Ghazy 2016; Brännvall 2017). Santos et al. (2015) studied the effect of acid pretreatment of E. grandis and $E$. urograndis wood chips prior to kraft pulping and reported several benefits, such as reduction in white liquor charge, increased pulp yield, and increased pulp viscosity and black liquor heating value. The carbohydrate contents were not adversely affected due to the acidic pretreatment (Santos et al. 2015). 


\section{Pulping of Destructured Wood Chips of E. tereticornis}

The effect of mechanical treatment by the Impressafiner was studied during the kraft pulping of E. tereticornis wood chips. The effect of temperature and active alkali variations were also studied for the destructured wood chips. The screened pulp yield increased as cooking temperature increased from 135 to $145^{\circ} \mathrm{C}$ and $\mathrm{H}$-factor from 73 to 185, whereas the Kappa number decreased sharply each time the temperature was measured. Beyond a temperature of $145{ }^{\circ} \mathrm{C}$ and $\mathrm{H}$-factor 185 , the screened pulp yield decreased significantly (Table 2). Therefore, $145^{\circ} \mathrm{C}$ (and H-factor 185) was selected as the optimum temperature to optimize the alkali dose in the next set of experiments. The effect of active alkali doses was studied from $12 \%$ to $20 \%$ at an interval of $2 \%$ alkali dose. The screened pulp yield increased as alkali dose increased until reaching 15\%, after which there was a sharp decrease in screened pulp yield. However, the Kappa number decreased sharply as active alkali dose increased from $12 \%$ to $20 \%$. Therefore, an active alkali dose of $15 \%$ was determined to be optimal for the delignification of destructured wood chips of E. tereticornis. The fiber length and width of E. tereticornis were 0.82 and $15 \mu \mathrm{m}$ respectively.

Table 2. Pulping of De-structured Wood Chips of E. tereticornis

\begin{tabular}{|c|c|c|c|c|c|c|}
\hline Parameters & $\begin{array}{c}\mathrm{H}- \\
\text { factor }\end{array}$ & $\begin{array}{c}\text { Pulp Yield } \\
(\%)\end{array}$ & $\begin{array}{c}\text { Screen } \\
\text { Rejects (\%) }\end{array}$ & $\begin{array}{l}\text { Screened } \\
\text { Pulp } \\
\text { Yield (\%) }\end{array}$ & Kappa No. & Pulping Conditions \\
\hline \multicolumn{7}{|c|}{ Temperature $\left({ }^{\circ} \mathrm{C}\right)$ Variation } \\
\hline $135 \pm 2$ & 73 & $48.9 \pm 0.56$ & $2.10 \pm 0.13$ & 46.8 & $31.7 \pm 0.22$ & \multirow{5}{*}{$\begin{array}{l}\text { Time from ambient } \\
\text { temperature to } 105^{\circ} \mathrm{C}= \\
45 \text { min, time from } 105^{\circ} \mathrm{C} \\
\text { to maximum temperature } \\
=60 \text { min, time at } \\
\text { maximum temperature = } \\
90 \text { min, bath ratio }=1: 3, \\
\text { active alkali } 15 \% \text { (as } \\
\mathrm{Na}_{2} \mathrm{O} \text { ), sulphidity }=25 \%\end{array}$} \\
\hline $140 \pm 2$ & 117 & $50.2 \pm 0.46$ & $1.25 \pm 0.03$ & 49.0 & $25.6 \pm 0.51$ & \\
\hline $145 \pm 2$ & 185 & $49.7 \pm 0.48$ & $0.35 \pm 0.06$ & 49.4 & $24.4 \pm 0.37$ & \\
\hline $150 \pm 2$ & 290 & $48.5 \pm 0.39$ & $0.25 \pm 0.04$ & 48.2 & $23.8 \pm 0.53$ & \\
\hline $155 \pm 2$ & 450 & $47.0 \pm 0.27$ & $0.20 \pm 0.05$ & 46.8 & $21.0 \pm 0.44$ & \\
\hline \multicolumn{7}{|c|}{ Active Alkali (\%) Variation } \\
\hline 12 & & $49.6 \pm 0.46$ & $1.25 \pm 0.14$ & 48.4 & $29.2 \pm 0.23$ & \multirow{6}{*}{$\begin{array}{l}\text { Time from ambient } \\
\text { temperature to } 105^{\circ} \mathrm{C}= \\
45 \mathrm{~min} \text {, time from } 105^{\circ} \mathrm{C} \\
\text { to } 145^{\circ} \mathrm{C}=60 \mathrm{~min} \text {, time } \\
\text { at } 145^{\circ} \mathrm{C}=90 \mathrm{~min} \text {, bath } \\
\text { ratio }=1: 3 \text {, sulphidity }= \\
25 \% \text {, active alkali doses } \\
=\text { varied from } 12 \% \text { to } \\
20 \% \text { (as } \mathrm{Na}_{2} \mathrm{O} \text { ) }\end{array}$} \\
\hline 14 & & $49.2 \pm 0.50$ & $0.64 \pm 0.11$ & 48.7 & $26.1 \pm 0.22$ & \\
\hline 15 & & $49.4 \pm 0.27$ & $0.25 \pm 0.17$ & 49.2 & $24.2 \pm 0.38$ & \\
\hline 16 & & $47.4 \pm 0.68$ & $0.15 \pm 0.28$ & 47.3 & $23.2 \pm 0.16$ & \\
\hline 18 & & $46.2 \pm 0.55$ & $0.10 \pm 0.15$ & 46.10 & $22.2 \pm 0.33$ & \\
\hline 20 & & $45.8 \pm 0.32$ & $0.10 \pm 0.17$ & 45.7 & $19.2 \pm 0.13$ & \\
\hline
\end{tabular}

A screened pulp yield of $49.1 \%$ with a Kappa number of 24.9 was observed at a cooking temperature of $160{ }^{\circ} \mathrm{C}$ during the kraft pulping of non-destructured wood chips. In addition, a similar screened pulp yield (49.4\%) and Kappa number (24.4) were observed at a cooking temperature of $145^{\circ} \mathrm{C}$ during the kraft pulping of mechanically destructured wood chips. These results indicated saving in electrical energy in terms of cooking temperature reduction of $15{ }^{\circ} \mathrm{C}$ for mechanically destructured wood chips. The mechanical treatment broke the compact structure of the wood chips and converted the wood chips into a spongy material. Further, the mechanical treatment opened the compact fibers to improve the accessibility of pulping chemicals to the interior of the fibers (Gupta et al. 2013). The improvement in the penetration of white liquor resulted in improved delignification of destructured wood chips at lower temperature. 


\section{Pulping of Destructured-xylanase-treated (DXT) Wood Chips of $E$. tereticornis}

The effect of the combined mechanical and xylanase treatment of wood chips was studied at different cooking temperatures and active alkali doses. Figure 3 shows an overview of pulping of DXT wood chips of E. tereticornis.
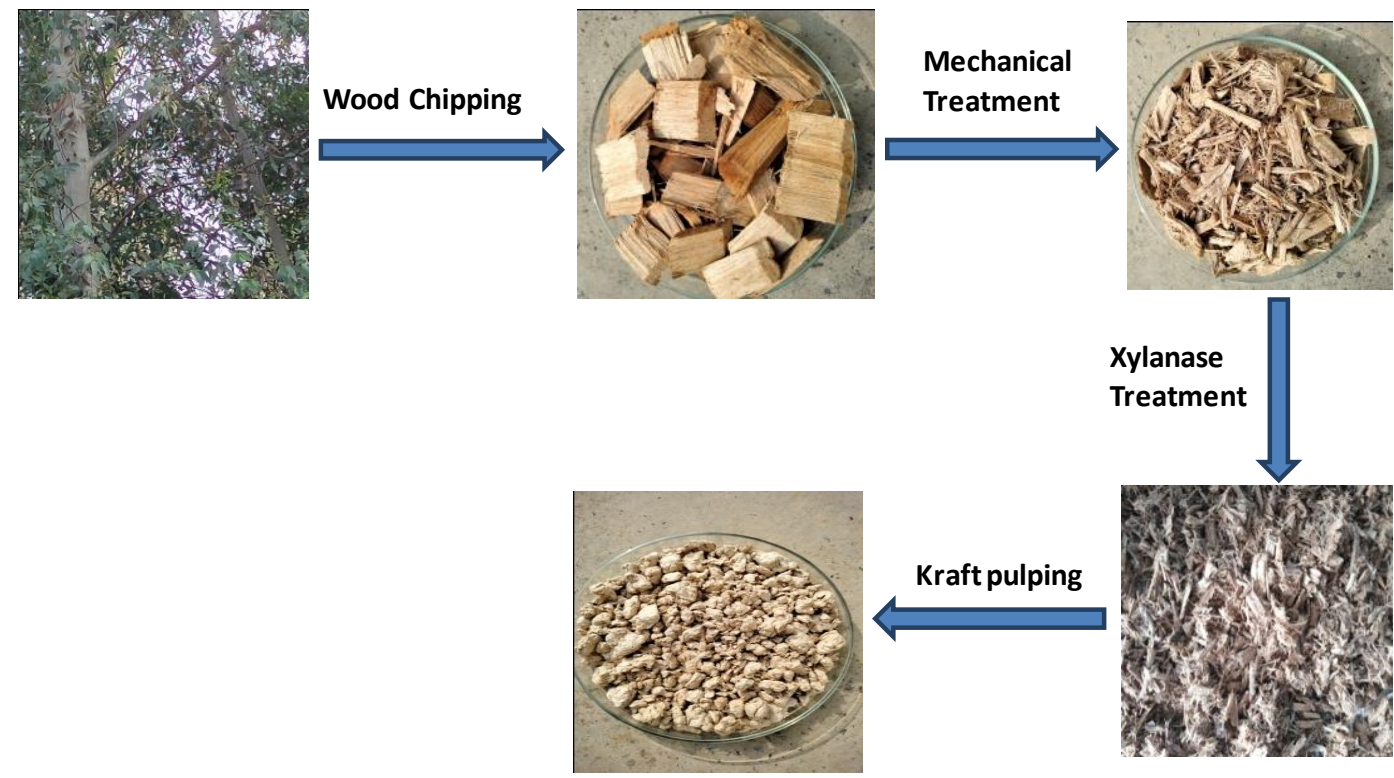

Fig. 3. Process overview for pulping of mechanically DXT wood chips

Table 3. Pulping of DXT Wood Chips of E. tereticornis

\begin{tabular}{|c|c|c|c|c|c|c|}
\hline Parameter & $\begin{array}{c}\mathrm{H}- \\
\text { factor }\end{array}$ & $\begin{array}{c}\text { Pulp Yield } \\
(\%)\end{array}$ & $\begin{array}{c}\text { Screen } \\
\text { Rejects (\%) }\end{array}$ & $\begin{array}{c}\text { Screened } \\
\text { Pulp Yield } \\
(\%)\end{array}$ & Kappa No. & Pulping Conditions \\
\hline \multicolumn{7}{|c|}{ Temperature $\left({ }^{\circ} \mathrm{C}\right)$ Variation } \\
\hline $135 \pm 2$ & 73 & $48.6 \pm 0.46$ & $1.88 \pm 0.09$ & 46.5 & $18.8 \pm 0.32$ & \multirow{5}{*}{$\begin{array}{l}\text { Time from ambient } \\
\text { temperature to } 105^{\circ} \mathrm{C}= \\
45 \text { min, time from } 105^{\circ} \mathrm{C} \\
\text { to maximum temperature } \\
=90 \text { min, bath ratio }= \\
1: 3 \text {, active alkali }=15 \% \\
\left(\mathrm{Na}_{2} \mathrm{O}\right) \text {, sulphidity }=25 \%\end{array}$} \\
\hline $140 \pm 2$ & 117 & $48.1 \pm 0.57$ & $0.69 \pm 0.02$ & 47.4 & $18.2 \pm 0.41$ & \\
\hline $145 \pm 2$ & 185 & $47.2 \pm 0.44$ & $0.50 \pm 0.05$ & 46.7 & $16.4 \pm 0.57$ & \\
\hline $150 \pm 2$ & 290 & $46.2 \pm 0.39$ & $0.30 \pm 0.03$ & 45.9 & $15.9 \pm 0.23$ & \\
\hline $155 \pm 2$ & 450 & $45.1 \pm 0.22$ & $0.10 \pm 0.06$ & 45.0 & $13.2 \pm 0.64$ & \\
\hline \multicolumn{7}{|c|}{ Active Alkali (\%) Variation $\left(140{ }^{\circ} \mathrm{C}\right)$} \\
\hline \multicolumn{2}{|c|}{12} & $48.8 \pm 0.23$ & $1.90 \pm 0.12$ & 46.9 & $24.7 \pm 0.33$ & \multirow{6}{*}{$\begin{array}{l}\text { Time from ambient } \\
\text { temperature to } 105^{\circ} \mathrm{C}= \\
45 \mathrm{~min} \text {, time from } 105^{\circ} \mathrm{C} \\
\text { to } 140^{\circ} \mathrm{C}=90 \text { min, bath } \\
\text { ratio }=1: 3 \text {, temperature }= \\
140^{\circ} \mathrm{C} \text {, sulphidity }=25 \% \text {, }\end{array}$} \\
\hline \multicolumn{2}{|c|}{14} & $48.5 \pm 0.54$ & $1.20 \pm 0.10$ & 47.3 & $21.4 \pm 0.32$ & \\
\hline \multicolumn{2}{|c|}{15} & $48.1 \pm 0.57$ & $0.69 \pm 0.02$ & 47.4 & $18.2 \pm 0.41$ & \\
\hline \multicolumn{2}{|c|}{16} & $47.1 \pm 0.55$ & $0.40 \pm 0.19$ & 46.7 & $16.9 \pm 0.20$ & \\
\hline \multicolumn{2}{|c|}{18} & $45.5 \pm 0.48$ & $0.32 \pm 0.13$ & 45.2 & $14.7 \pm 0.19$ & \\
\hline \multicolumn{2}{|c|}{20} & $43.8 \pm 0.37$ & $0.10 \pm 0.20$ & 43.7 & $13.4 \pm 0.11$ & \\
\hline
\end{tabular}

The wood chips were first mechanically destructured and then pretreated with xylanase (20 IU/g of oven-dried substrate) before pulping. The cooking temperature was varied from 135 to $145^{\circ} \mathrm{C}$ and $\mathrm{H}$-factor from 73 to 185 at an interval of $5{ }^{\circ} \mathrm{C}$. The screened pulp yield increased to $47.4 \%$ with a sharp reduction in screening rejects. Further increases in temperature resulted in a significant decrease in both screened pulp yield and Kappa 
number (Table 3). Therefore, $140{ }^{\circ} \mathrm{C}$ was determined to be the optimum cooking temperature for DXT wood chips of E. tereticornis. An active alkali dose of $15 \%$ was found most suitable for improving screened pulp yield (47.4\%) and reducing the Kappa number (18.2). Active alkali doses beyond $15 \%$ reduced the Kappa number and screened pulp yield sharply.

The objective of mechanical and xylanase pretreatment was to make the raw material more suitable for pulping and papermaking. The comparative analysis of the pulping of destructured and DXT wood chips showed that xylanase pretreatment decreased the screened pulp yield from $49.4 \%$ to $47.4 \%$. In addition, the xylanase pretreatment resulted in a Kappa number reduction by $26.9 \%$ relative to the control (without any pretreatment). The cooking temperature was also lowered by $5{ }^{\circ} \mathrm{C}$ after xylanase pretreatment. If the cooking temperature were lowered by $5{ }^{\circ} \mathrm{C}$, it would reduce the energy requirement during pulping. The compact structure of wood chips was broken during mechanical treatment, and the wood chips were converted into spongy material. The mechanical treatment loosened the compact structure of the fibers and improved the accessibility of xylanase to the fibers (Gupta et al. 2013). The decreased screened pulp yield and reduced Kappa number indicated that there was better xylanase penetration, and it acted on the xylan. The xylanase treatment hydrolyzed the xylan, broke down the lignincarbohydrate bonds, and opened the polymer to facilitate the removal of lignin by white liquor during pulping and decreased the Kappa number of resultant pulp (Akgül et al. 2021; Gautam et al. 2021). Varghese et al. (2020b) performed a xylano-pectinolytic enzyme pretreatment of sugarcane bagasse before soda-anthraquinone pulping. The maximum effect of the enzyme treatment was reported with an enzyme dose of xylanase $(175 \mathrm{IU} / \mathrm{g}$ bagasse) and pectinase (75 IU/g bagasse) and treatment duration of $180 \mathrm{~min}$. The enzyme pretreatment reduced the Kappa number $49.1 \%$ compared to the control. Similarly, the enzyme treatment also reduced the requirement of active alkali by $15 \%$ to attain a Kappa number similar to that obtained with $100 \%$ active alkali (Varghese et al.2020b). In another study, the pretreatment of wheat straw was performed with a crude xylano-pectinolytic concoction with a xylanase dose of $400 \mathrm{IU} / \mathrm{g}$ wheat straw and a pectinase dose of $120 \mathrm{IU} / \mathrm{g}$ wheat straw at $55{ }^{\circ} \mathrm{C}$ for $3 \mathrm{~h}$ of treatment (Varghese et al. 2020a). The enzymatic pretreatment resulted in a $15.67 \%$ reduction in Kappa number, and the pulp brightness was improved $16.04 \%$. Moreover, the pulping chemical requirement decreased $12 \%$ relative to the control (without enzyme treatment) (Varghese et al. 2020a).

\section{Effect of Mechanical and Xylanase Pretreatment on Strength Properties}

The maximum pulp brightness (34\% ISO) was observed for DXT wood chips rather than non-destructured or destructured wood chips. The higher brightness of pulp from DXT was attributed to increased removal of lignin-carbohydrate complexes due to xylanase pretreatment. The kraft pulp produced by the 3 different treatments was analyzed for physical strength properties at a fixed beating level of $35 \pm 2{ }^{\circ} \mathrm{SR}$. The xylanase pretreatment improved the tensile index of the pulp by $11.06 \%$ and $6.74 \%$ compared to non-destructured and destructured wood chips, respectively. Similarly, destructured-xylanase treatment caused slight improvements in the tear and burst indexes compared to non-destructured and destructured wood chips (Table 4). The xylanase hydrolyzed the xylan, caused the separation of the secondary wall, and increased the surface area by fibrillation, which improved the fiber-to-fiber bonding. The improved fiber-to-fiber bonding may have improved the physical strength properties (Akgül et al. 2021; Kumar et al. 2021). The FESEM analysis of the pulp samples also indicated that there was improved fiber bonding for 
the destructured-xylanase treated pulp samples (Fig. 3). Akgül et al. (2021) performed xylanase pretreatment before the Kraft pulping of poplar and reported $28.18 \%$ and $25.27 \%$ improvements in tensile index and burst index, respectively, compared to the control (without xylanase pretreatment). Varghese et al. (2020b) pretreated sugarcane bagasse with xylano-pectinolytic enzyme before chemical pulping and found $13.55 \%, 40.21 \%, 19.04 \%$, and $42.5 \%$ improvements in breaking length, burst index, tear index, and double fold numbers, respectively.

Table 4. Comparison of Strength and Optical Properties of Pulp from Nondestructured, Destructured, and DXT Wood Chips

\begin{tabular}{|c|c|c|c|c|c|c|}
\hline $\begin{array}{c}\text { Type of } \\
\text { Treatment }\end{array}$ & $\begin{array}{c}\text { Tensile } \\
\text { Index } \\
(\mathbf{N m} / \mathbf{g})\end{array}$ & $\begin{array}{c}\text { Tear Index } \\
\left(\mathbf{m N}^{\star} \mathbf{m}^{\mathbf{2}} \mathbf{g}\right)\end{array}$ & $\begin{array}{c}\text { Burst } \\
\text { Index } \\
\left(\mathbf{k P a ~ m}^{\mathbf{2}} \mathbf{g}\right)\end{array}$ & $\begin{array}{c}\text { ISO } \\
\text { Brightness } \\
(\%)\end{array}$ & $\begin{array}{c}\text { Bulk } \\
\left(\mathbf{c m}^{\mathbf{3}} \mathbf{/ g}\right)\end{array}$ & $\begin{array}{c}\text { Double } \\
\text { Fold } \\
\text { (Numbers) }\end{array}$ \\
\hline $\begin{array}{c}\text { Non- } \\
\text { destructured }\end{array}$ & $55.42 \pm 2.3$ & $5.57 \pm 0.21$ & $3.12 \pm 0.11$ & $32 \pm 0.3$ & $\begin{array}{c}1.66 \\
\pm 0.03\end{array}$ & $340 \pm 4$ \\
\hline Destructured & $57.66 \pm 2.8$ & $6.22 \pm 0.35$ & $3.74 \pm 0.20$ & $32 \pm 0.4$ & $\begin{array}{c}1.65 \pm \\
0.05\end{array}$ & $360 \pm 7$ \\
\hline DXT & $61.55 \pm 3.1$ & $6.78 \pm 0.32$ & $3.80 \pm .13$ & $34 \pm 0.3$ & $\begin{array}{c}1.76 \pm \\
0.02\end{array}$ & $370 \pm 6$ \\
\hline
\end{tabular}

\section{Morphological Analysis of Pulp}

Analysis of the FE-SEM images showed that the separation of fibers was improved for pulp obtained from mechanically destructured wood chips compared to non-destuctured wood chips (Fig.4a-b).

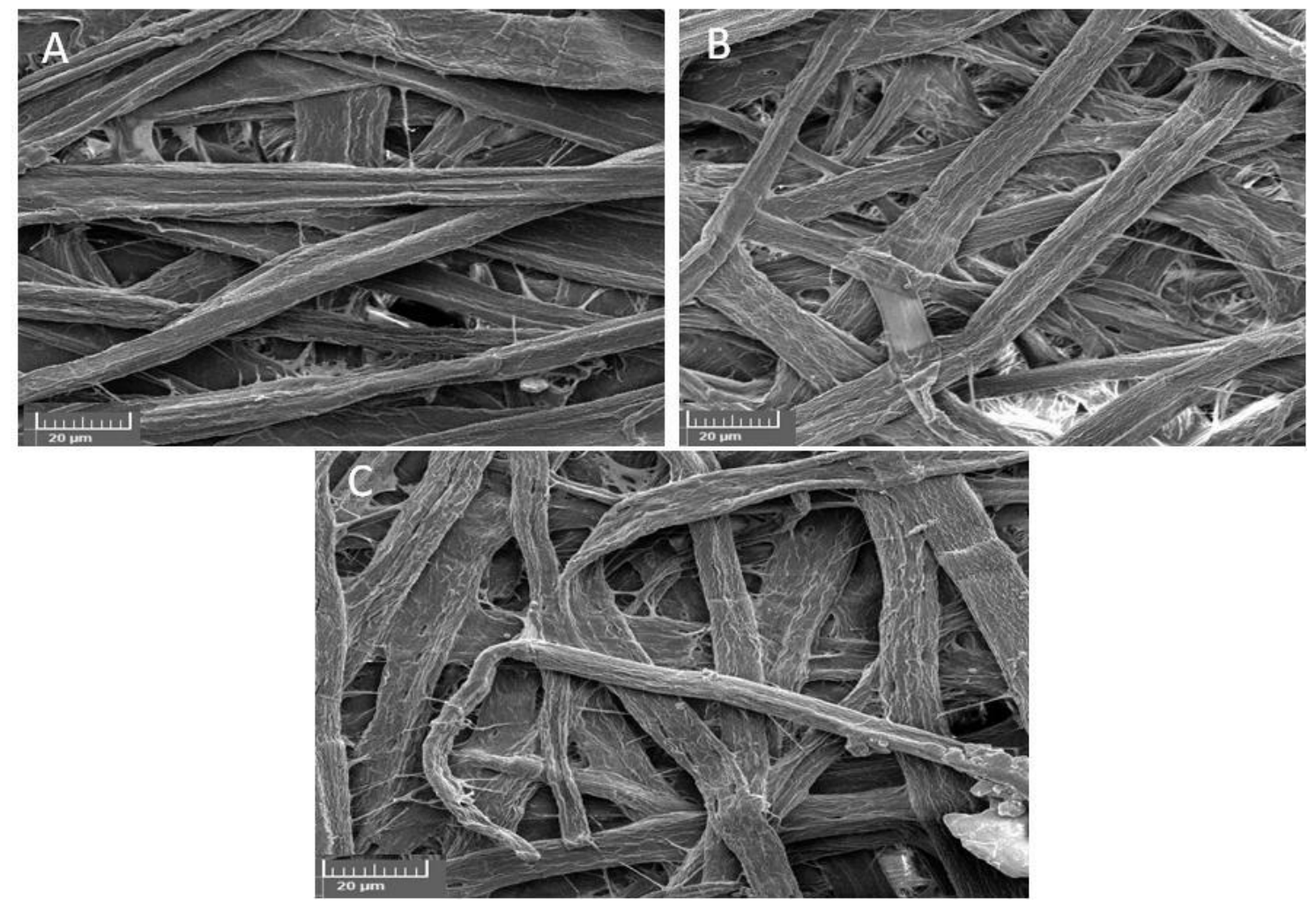

Fig. 4. Morphological analysis of pulp: (A) non-destructured pulp fiber (1.0 kx); (B) destructured (mechanical) pulp fiber (1.0 kx); (C) DXT pulp fiber (1.0 kx) 
The DXT samples exhibited increased swelling, peeling, and loosening of pulp fibers. The fiber roughness increased for the xylanase treated pulp samples. The FE-SEM analysis showed prominent external fibrillation in xylanase pretreated pulp samples, which was supported by the improved physical strength properties (Fig. 3c). The changes in surface structure indicated that xylan hydrolysis occurred (Nagar et al. 2013).

\section{FTIR Analysis}

Figure 5 shows the FTIR spectra of the pulp samples from the three treatments. The band at 2893 to $2900 \mathrm{~cm}^{-1}$ was attributed to the $\mathrm{C}-\mathrm{H}$ stretching of the methyl/methylene groups of cellulose and hemicelluloses for pulp from non-destructured wood chips. The band shifted to $2912 \mathrm{~cm}^{-1}$ for mechanically destructured wood chips. The shifting effect was more pronounced after the xylanase treatment of destructured wood chips and reached approximately $2926 \mathrm{~cm}^{-1}$. This may have been due to the change in the environment around the $\mathrm{C}-\mathrm{H}$ bond due to removal of hemicelluloses and lignin during treatments (Chen et al. 2015; Dowarah et al. 2020). The band at $1512 \mathrm{~cm}^{-1}$ was assigned to the vibration of the aromatic ring in lignin. This band disappeared in the pulp obtained from the mechanical and xylanase treatments due to removal of lignin (Kumar et al. 2016b).

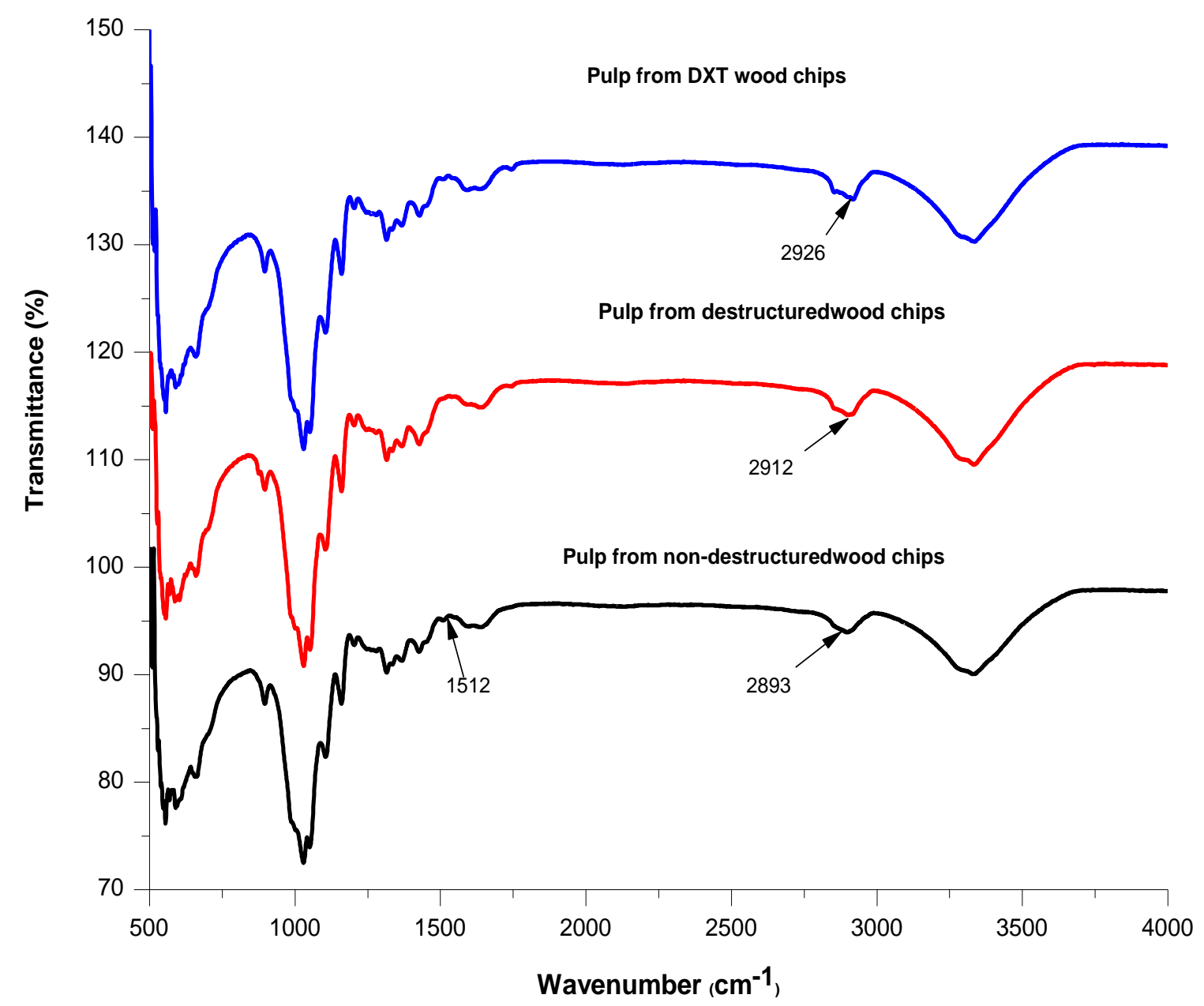

Fig. 5. The FTIR spectra of non-destructured, destructured, and DXT pulp samples 


\section{CONCLUSIONS}

1. The combined mechanical and xylanase pretreatment effectively reduced energy consumption during the kraft pulping of E. tereticornis.

2. The combined pretreatment reduced the cooking temperature $20{ }^{\circ} \mathrm{C}$ and $\mathrm{H}$-factor 546 compared to control (without any pretreatment) and reduced the Kappa number of the resultant pulp 26.9\%.

3. The reduction in temperature could save steam during kraft pulping.

4. The combined pretreatment improved the physical strength properties of the resultant pulp compared to the control.

\section{ACKNOWLEDGMENTS}

The first author is thankful to the Ministry of Human Resource Development, Government of India for providing him fellowship to carry out this work.

\section{REFERENCES CITED}

Akgül, M., Gucus, M. O., Üner, B., and Atik, C. (2021). "Effect of xylanase pretreatment on the kraft pulping of poplar," BioResources 16(1), 979-986. DOI: 10.15376/biores.16.1.979-986.

Bajpai, P. (2018). "Biopulping," in: Biotechnology for Pulp and Paper Processing, P. Bajpai (ed.), Springer International Publishing, Singapore, pp.67-92. DOI: 10.1007/978-981-10-7853-8

Bari, E., Ohno, K., Yilgor, N., Singh, A. P., Morrell, J. J., Pizzi, A., Tajick Ghanbary, M. A., and Ribera, J. (2021). "Characterizing fungal decay of beech wood: Potential for biotechnological applications," Microorganisms 9(2), article no. 247.DOI: $10.3390 /$ microorganisms 9020247

Brännvall, E. (2017). "The limits of delignification in kraft cooking," BioResources12(1), 2081-2107. DOI: 10.15376/biores.12.1.2081-2107

Chen, Y., Wan, J., Ma, Y., Dong, X., Wang, Y., and Huang, M. (2015). "Fiber properties of de-inked old newspaper pulp after bleaching with hydrogen peroxide," BioResources 10(1), 1857-1868. DOI: 10.15376/biores.10.1.1857-1868

Dowarah, P., Neog, B., and Goswami, T. (2020). "Xylanase enzyme production from Bacillus australimaris P5 for prebleaching of bamboo (Bambusa tulda) pulp," Materials Chemistry and Physics 243, article ID122227. DOI: 10.1016/j.matchemphys.2019.122227

Ezeudu, O. B., Agunwamba, J. C., Ezeasor, I. C., and Madu, C. N. (2019). "Sustainable production and consumption of paper and paper products in Nigeria: A review," Resources8(1), Number53. DOI: 10.3390/resources8010053

Gautam, A., Kumar, A., and Dutt, D. (2016). "Effects of ethanol addition and biological pretreatment on soda pulping of Eulaliopsis binata," Journal of Biomaterials and Nanobiotechnology 2016(7), 78-90. DOI: 10.4236/jbnb.2016.72010

Gautam, A., Kumar, A., and Dutt, D. (2021). "Biobleaching of ethanol-soda pulp of 
Eulaliopsis binata by xylanases from Aspergillus flavus ARC-12 and Schizophyllum commune ARC-11," Journal of Microbiology, Biotechnology and Food Sciences10(5), 669-673. DOI: 10.15414/jmbfs.2021.10.4.669-673

Ghazy, M. B. M. (2016). "Effect of temperature and time on the kraft pulping of Egyptian bagasse," International Journal of Science and Research 5(2), 179-184. DOI: $10.21275 / \mathrm{v} 5 \mathrm{i} 2 . n o v 161065$

Gupta, R., Saini, V. K., Bhatt, R. P., Thapliyal, B. P., and Naithani, S. (2013). "Influence of mechanical operation on the biodelignification of Eucalyptus tereticornis by Trametes versicolor," Cellulose Chemistry and Technology47(9-10), 759-764.

Karinkanta, P. (2014). Dry Fine Grinding of Norway Spruce (Picea abies) Wood in Impact-Based Fine Grinding Mills, Ph.D. Dissertation, University of Oulu, http://jultika.oulu.fi/Record/isbn978-952-62-0719-3.

Karinkanta, P., Ämmälä, A., Illikainen, M., and Niinimäki, J. (2018). "Fine grinding of wood - Overview from wood breakage to applications," Biomass and Bioenergy 113, 31-44.

Knapic, S., Pirralho, M., Louzada, J. L., and Pereira, H. (2014). "Early assessment of density features for 19 Eucalyptus species using X-ray microdensitometry in a perspective of potential biomass production," Wood Science and Technology 48(1), 37-49. DOI: $10.1007 / \mathrm{s} 00226-013-0579-y$

Kumar, A., Dutt, D., and Gautam, A. (2016a). "Production of crude enzyme from Aspergillus nidulans AKB-25 using black gram residue as the substrate and its industrial applications," Journal of Genetic Engineering and Biotechnology 14(1),107-118. DOI: 10.1016/j.jgeb.2016.06.004

Kumar, A., Dutt, D., and Gautam, A. (2016b). "Pretreatment and enzymatic hydrolysis of pearl millet stover by multi-enzymes from Aspergillus nidulans AKB-25," Cellulose Chemistry and Technology 50(7-8), 781-790.

Kumar, A. (2021). "Biobleaching: An eco-friendly approach to reduce chemical consumption and pollutants generation," Physical Sciences Reviews Online, (Accepted). DOI: 10.1515/psr-2019-0044

Kumar, A., Gautam, A., and Dutt, D. (2020). "Bio-pulping: An energy saving and environment-friendly approach," Physical Sciences Reviews 5(10), 1-9.DOI: 10.1515/psr-2019-0043

Kumar, A., Ram, C., and Tazeb, A. (2021). "Enzyme-assisted pulp refining: An energy saving approach," Physical Sciences Reviews 6(2), 1-20. DOI: 10.1515/psr-20190046

Lal, M., Dutt, D., Tyagi, C.H., Upadhyay, J. S., and Upadhyay, S. (2010). "Characterization of Anthocephalus cadamba and its delignification by kraft pulping," TAPPI Journal9(3), 30-37.

Nagar, S., Jain, R. K., Thakur, V. V., and Gupta, V. K. (2013). "Biobleaching application of cellulase poor and alkali stable xylanase from Bacillus pumilus SV-85S," 3 Biotech 3(4), 277-285. DOI: 10.1007/s13205-012-0096-y

Neiva, D., Fernandes, L., Araújo, S., Lourenço, A., Gominho, J., Simões, R., and Pereira, H. (2015). "Chemical composition and kraft pulping potential of 12 Eucalypt species," Industrial Crops and Products 66, 89-95. DOI: 10.1016/j.indcrop.2014.12.016.

Nelsson, E., Sandberg, C., Hildén, L., and Daniel, G. (2018). "Pressurised compressive chip pre-treatment of Norway spruce with a mill scale Impressafiner," Nordic Pulp and Paper Research Journal 27(1/2), 56-62. DOI: 10.3183/NPPRJ-2012-27-01-p056- 
062.

Nieschlag, H. J., Nelson, G. H., Woff, I. A., and Purdue, R. E. Jr, (1960). “A search for new fibre crops," TAPPI 43(3), 193-201.

Pandey, L. K., Bansal, M., Pathak, P., Dutt, D., Kumar, V., and Kumar, S. (2012). "Kinetics of delignification of bast fiber of jute plant (Corcorus capsularis) in alkaline pulping," Journal of Indian Pulp and Paper Technical Association 24(2), 123-127.

Rockwood, D. L., Rudie, A. W., Ralph, S. A., Zhu, J. Y., and Winandy, J. E. (2008). "Energy product options for Eucalyptus species grown as short rotation woody crops," International Journal of Molecular Sciences 9(8), 1361-1378. DOI: 10.3390/ijms9081361

Santos, R. B., Gomide, J. L., and Hart, P. W. (2015). "Kraft pulping of reduced metal content eucalyptus wood: Process impacts," BioResources 10(4), 6538-6547. DOI: 10.15376/biores.10.4.6538-6547

Sharma, D., Chaudhary, R., Kaur, J., and Arya, S. K. (2020). "Greener approach for pulp and paper industry by xylanase and laccase," Biocatalysis and Agricultural Biotechnology 25, Article ID101604. DOI: 10.1016/j.bcab.2020.101604.

Söderholm, P., Bergquist, A. K., and Söderholm, K. (2019). "Environmental regulation in the pulp and paper industry: Impacts and challenges," Current Forestry Reports 5, 185-198. DOI: $10.1007 / \mathrm{s} 40725-019-00097-0$

TAPPI T203 cm-99 (1999). “Alpha-, beta- and gamma-cellulose in pulp,” TAPPI Press, Atlanta, GA, USA.

TAPPI T205 sp-02 (2002). "Forming handsheets for physical tests of pulp," TAPPI Press, Atlanta, GA, USA.

TAPPI T218 sp-02 (2002). "Forming handsheets for reflectance testing of pulp" (Büchner funnel procedure)," TAPPI Press, Atlanta, GA, USA.

TAPPI T222 om-02 (2006). “Acid-insoluble lignin in wood and pulp," TAPPI Press, Atlanta, GA, USA.

TAPPI T236 om-99 (1999). “Kappa number of pulp,” TAPPI Press, Atlanta, GA, USA.

TAPPI T249 cm-85 (2009). "Carbohydrate composition of extractive-free wood and wood pulp by gas-liquid chromatography," TAPPI Press, Atlanta, GA, USA.

TAPPI T264 cm-97 (1997). "Preparation of wood for chemical analysis," TAPPI Press, Atlanta, GA, USA.

TAPPI T402 sp-03 (2003). "Standard conditioning and testing atmospheres for paper, board, pulp handsheets, and related products," TAPPI Press, Atlanta, GA, USA.

TAPPI T403 om-97 (1997). "Bursting strength of paper," TAPPI Press, Atlanta, GA, USA.

TAPPI T414 om-04 (2004). "Internal tearing resistance of paper (Elemendrof-type method)," TAPPI Press, Atlanta, GA, USA.

TAPPI T423 cm-98 (1998). "Folding endurance of paper," TAPPI Press, Atlanta, GA, USA.

TAPPI T452 om-02 (2002). "Brightness of pulp, paper, and paperboard (directional reflectance at $457 \mathrm{~nm}$ )," TAPPI Press, Atlanta, GA, USA.

TAPPI T494 om-01 (2001). "Tensile properties of paper and paperboard (using constant rate of elongation apparatus)," TAPPI Press, Atlanta, GA, USA.

Varghese, L. M., Agrawal, S., Nagpal, R., Mishra, O. P., Bhardwaj, N. K., and Mahajan, R. (2020a). "Eco-friendly pulping of wheat straw using crude xylano-pectinolytic concoction for manufacturing good quality paper," Environmental Science and 
Pollution Research 27, 34574-34582.DOI: 10.1007/s11356-020-10119-1

Varghese, L. M., Nagpal, R., Singh, A., Mishra, O. P., Bhardwaj, N. K., and Mahajan, R. (2020b). "Ultrafiltered biopulping strategy for the production of good quality pulp and paper from sugarcane bagasse," Environmental Science and Pollution Research 27, 44614-44622. DOI: 10.1007/s11356-020-11102-6

Zhou, H., St. John, F., and Zhu, J. Y. (2019). "Xylanase pretreatment of wood fibers for producing cellulose nanofibrils: A comparison of different enzyme preparations," Cellulose 26(1), 543-555. DOI: 10.1007/s10570-019-02250-1

Article submitted: March 12, 2021; Peer review completed: May 9, 2021; Revised version received: June 4, 2021; Accepted: June 6, 2021; Published: June 10, 2021. DOI: 10.15376/biores.16.3.5361-5375 